\title{
POLITICS AND THE BLACK AMERICAN
}

John Hall Fish, Black Power/White Control. Princeton University Press, 1973. Pp. 356. \$12.50.

Matthew Holden, Jr., The Politics of the Black "Nation." Chandler Publishing Company, 1973. Pp. 235. \$12.00, paper $\$ 5.95$.

Matthew Holden, Jr., The White Man's Burden. Chandler Publishing Company, 1973. Pp. 284. Paper, $\$ 5.95$.

Mary Manoni, Bedford-Stuyvesant: The Anatomy of a Central City Community. Quadrangle Books, 1973. Pp. 118. \$6.95. Hanes Walton, Jr., Black Politics: A Theoretical and Structural Analysis. Lippincott Company, 1972. Pp. 246. Paper, \$4.95.

Approximately seventy years ago W.E.B. DuBois stated in an essay "Of The Dawn of Freedom" that: "The problem of the twentieth century is the problem of the color-line,-the relation of the darker to the lighter races of men in Asia and Africa, in America and the islands of the sea." History has given witness to this prognostication, for race relations problems have been at the forefront of this century's struggle. Scholars in the past as well as the present continue to lend their skills to the understanding, and hopeful eradication, of this problem.

This essay reviews the works of several scholars who have attempted to analyze the racial problem in America. Most of these works were published within the last three years and represent many new and refreshing ideas concerning the problem. Some of the authors focus on the general nature of the problem, while others focus on pacticular features within certain areas, i.e., urban life. 
The first book is a collection of essays written by Professor Matthew Holden, Jr. titled The Politics of the Black "Nation." Here we get the relationship of the black community to the white community. Holden does this by analyzing the politics within the black community, and telling how it relates to the white community.

Professor Holden discusses the politics of the black "nation" by referring to groups and institutions within the black community. Such groups as the Urban League and the National Association for the Advancement of Colored People (NAACP) and the various leaders of these community groups make up the "Quasi government" within the black nation. We do not get a very clear definition of nation, but he states in essence that this a sociocultural nation, having boundaries along racial lines. This is probably why Holden places nation in quotation marks and refers to the government as "quasi." (This may be a trivial observation, but it could be essential to the overall understanding of the presentation.) An unqualified definition of nation would certainly run into problems with those scholars who have defined nations in terms of geography, governmental systems, and legal structures. However, this does not pose a serious problem for Holden's sociocultural nation simply because it only describes a nation within a nation, divided by racial antagonism. As he puts it: "The central thread is the concept of race schism as a republican crisis, a problem of reconciling (or failing to reconcile) two sociocultural 'nations' within the same polity."

The black nation (as any nation) must deal with internal and external affairs which are vital to its viability. The problem of finding and maintaining resources of finance and organizational skills, along with those of building symbols and ideologies, is viewed as a major weakness within the black nation, and reduces its capacity to be "effective vis-á-vis the white world." Regardless of these problems, however, it must deal with its external affairs, i.e., with the white "nation." Holden gives three methods of dealing with the black nation's external policy: (1) clientage, where the objective is to "find a basis for coexistence by choosing objectives which the more influential outsiders (in this case whites) will support, and by their support offer protection against those outsiders who are your irreconcilable enemies"; (2) opposition, which entails use of moral persuasion to get the opposite nation to obey some general rule or moral principle. In this case the general rule is the constitution of the United States which applies to both nations. (3) Withdrawal involves some separatism (culture, value, or tactical) from the overall republic and functions in terms of "self determination" and a truly separate nation. 
Professor Holden proceeds to explain that it would not be feasible for the black nation to operate under the third-withdrawal-alternative. He points to similar problems in other nations (countries in the world) and attempts to show how their problems differ from those of the black nation, and must be dealt with by using "strategically" different methods. As he states: "The Third World is not a social system, but has its own internal divisions born of its own internal necessities. In this perspective the 'Third World' conception as ordinarily formulated is closely akin to suicide prescriptions if taken seriously, or if taken less seriously is but another form of ritualism not really meant to affect the social structure of the United States." Thus; the external affairs of the black nation should be geared toward seeking peaceful diplomatic relations with the white nation in the United States. In this way both will work to preserve the republic.

The black nation has been effectuating its political position (both internal and external) over a long period of time. This is what black politics is all about. As Professor Hanes Walton, Jr. points out in his work Black Politics: A Theoretical and Structural Analysis, it is a "function of the particular brand of segregation found in different environments in which black people find themselves." Simply put, black politics is the quest by black people for power, since politics is a "Quest for power." Walton develops his study of black politics by a developmental method which identifies four historical stages of black political participation: (1) nonparticipation, a stage where blacks were excluded from all entrances into the political arena; (2) limited participation, which was minor participation by a few blacks such as free Northern blacks during the pre-Civil-War period; (3) moderate participation, which is a point characterized by more than " 50 percent" participation, and where certain action within the general political arena is expected; (4) full participation, the stage where blacks are "mobilized in acting upon the political process to translate their choices into public policy."

According to Professor Walton, black political participation had its inception with petitions from slaves seeking freedom prior to 1779. After the War for Independence more blacks petitioned state governments for freedom. Some were successful, and they aided in forming organizations in attempts to obtain freedom for other blacks. This type of participation continued through the Civil War.

Black political participation was given impetus by the enactment of the thirteenth, fourteenth, and fifteenth amendments to the U.S. Constitution. Armed with this newly legal freedom, blacks began to vote and participate in political party affairs. Also, they began to use pressure 
politics to change policies relating to them. At the turn of the century groups such as the NAACP were formed to aid pressure politics for blacks.

Black Americans have moved from a position of nonparticipation to one of full participation and being able to influence public policy that affects them. With this development, blacks have been able to gain appointed and elected positions in government. Though this is a major step, it is by no means a revolutionary development, because black politics, Walton concludes, "must be seen for what it has been and is, a changing force in American politics."

The two works dealt with up to this point were concerned with black Americans within the general political setting. We will now turn to some works concerning blacks in particular urban settings. The first work considered here is Black Power/White Control by John Hall Fish. This is an analysis of an organization located in Chicago, Illinois within the predominately black Woodlawn community known as The Woodlawn Organization (TWO).

Professor Fish offers us a first hand view of the development of TWO because he participated in the organization for six years. This organization started in the early 1960s with the help of some Woodlawn citizens, Saul Alinsky, and several members of the clergy. It developed into a major influential organization within Woodlawn.

The thesis of Fish's argument concerns the "survival and growth of The Woodlawn Organization during a time when groups with similar objectives have met with little success." The organization first had to deal with problems of good leadership and to reconcile differences among members. Then it moved toward a struggle with the City of Chicago and the many institutions within it.

TWO began to establish plans for community development, but the organization had a major obstacle in Chicago--Mayor Richard Daley. Daley was more interested in the number of votes TWO could produce than in some plan for community development. Thus TWO would have to show Daley its muscles. This it did in terms of School Board picketing and writing counter-proposals to certain plans developed at City Hall. However, Daley had the upper hand-he was the elected official and could influence any plan or money coming from Washington affecting Chicago. TWO found that it could frustrate Daley's plan by going around him directly to Washington, but in the final analysis, it discovered that it had to deal with Daley. As Fish puts it: "In order to achieve and maintain its spokesman claim, TWO had to work within the constraints of the existing political process and to develop a base of power in ways that did not basically threaten the system and elicit forceful counterpressure." 
TWO was able to secure funds to establish a neighborhood youth program. The main objective was to bring a halt to the gang warfare within the community. The program started successfully with several gang members among the administrators of the program. TWO and several church organizations had problems with the city police administrator who did not like the idea of gang members operating the youth program. The conflict subsequently lead to the abolition of the program.

Another major problem for TWO was with the public schools and the University of Chicago. The University, located on the border of Woodlawn, sought funds for a major educational center for research and development from the U.S. Office of Education. Though the center was to be located in Woodlawn, the University did not include TWO in the planning of this massive education project. TWO protested to the University and Washington, and after receiving some reconciliation from the University, endorsed the program.

Professor Fish concludes in essence that TWO survived because the organization made changes that were essential to its survival. The organization was in conflict both within and without concerning many of its policy positions. For example, it learned that in obtaining federal support, it was only a "pawn in some larger contest, either between various federal agencies or between federal and Chicago governments." However, the organization received grants from several private corporations for community development programs. It is obvious that these businesses would not have invested in the organization had it not demonstrated manageability and soundness. Although TWO was not able to accomplish everything it wanted-such as community control of schools-it did have an influence on most public programs operating within the community.

Another analysis of a small, predominately black community is Professor Mary Manoni's Bedford-Stuyvesant: The Anatomy of a Central City Community. It differs from the analysis of TWO in that it discusses the make-up of a microcosm of the New York City metropolitan area, rather than the influence of a particular organization. Manoni takes on the task of understanding the economic, political, and social nature of the people that live in Bedford-Stuyvesant (Bed-Stuy).

The people living in Bed-Stuy generally migrated there from either Harlem, the southern states, or the West Indies. Blacks and Puerto Ricans make up the larger percentage of the population, with a few older whites who did not or could not leave the community once blacks started settling in. Bed-Stuy residents have organized clubs and other associations for the purpose of community development. 
On the economic scale, Bed-Stuy would be characterized as poor with a median income of $\$ 5,806$ for blacks and $\$ 5,054$ for Puerto Ricans, and approximately one-fifth of the population on some form of welfare. Many citizens are either unemployed or working part-time jobs. Most people spend their small earnings within their community in support of small businessmen. As Manoni relates: "Strongly in evidence is the feeling that community businesses, supported by community people, will result in a stronger ethnic identity."

Professor Manoni discusses several other problems in Bed-Stuy such as health, education, and crime. The overall health of the community is poor, with an infant mortality rate that doubles the norm. Health centers are generally overcrowded and many citizen knowing this do not seek proper care. Thus, such diseases as tuberculosis, lead poisoning, and even drug addiction many times go undetected. The schools are old structures, and the curriculum has a strong emphasis on vocational training, "although many of the vocations for which the student is being trained are rapidly being phased out of the nation's work picture." Crime, both organized and unorganized, causes many problems for citizens and the police. Many citizens fear walking to the bank or store to cash checks because of the high rate of street crimes. Policy gambling and drugs are said to be among the activities of organized crime in Bed-Stuy.

Manoni suggests that one way of coping with the problems in Bed-Stuy is more community 'involvement. In today's language, this has become a much overworked word. But it's the key to every thing in BedfordStuyvesant that has an upward bound direction." The federal government and some private agencies have given funds for community projects. But the citizens must relate to their community, its life and viability.

In order to cope with many of the problems experienced by black Americans, there must be major changes in policy distribution in the country. For an analysis of this point we turn finally to another collection of essays by Professor Matthew Holden, Jr. titled The White Man's Burden.

Holden expounds more on the "republican crisis' by defining "nation" as he did before. However, here he talks more about the white nation. He sees the major problem within the white nation as racism. "Racism is a set of values and beliefs which have to be held by persons and which broadly assume the biogenetic inferiority of one set of human beings and the superiority of another." It may be institutional or "quasiracism." The objective is to eradicate racism and other obstacles in the way of "creating a politics of social peace." The survival of the republic demands this! Public policy must work toward economic and social benefits that are 
equally distributed so that blacks will receive their fair share. Black unemployment should not double white, and black's income should not be less than that of whites for equal work. Although many of these policy questions cannot be answered immediately, the "policy problem is to make a start on those measures which will move in that direction." Hopefully in the not-to-distant future, we will overcome the "republican crisis" of racial schism.

These books dealt with the problem of race relations in the United States. This problem has plagued the country for years. Therefore, for the most part, we were presented with fresh ways to look into an old problem. It is important, however, to understand that the problem does exist. The problem is that a person's skin color is a function of his position in this country. For the most part, his skin color handicaps him-if he was white, his chances to obtain employment, education, and decent housing would be greater. The continuing question then is why? Maybe someone should look into the politics of race relations. Is it politically feasible to have race schism? Does it profit the political system to have racial antagonism?

I have not attempted a critical analysis of any of these works, but rather let them stand as they are. They raise important questions concerning black/white race relations. It seems that Professor Gunnar Myrdal's observation in An American Dilemma that America is free to choose whether blacks shall remain her "liability or become her opportunity" still has some validity.

-Nolan E. Jones

University of Michigan 